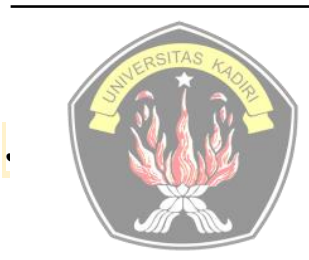

Tersedia online di

http://ojs.unik-kediri.ac.id/index.php/ekonika

do:

http://dx.doi.org/10.30737/ekonika.v5i1.520

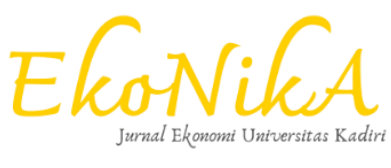

\title{
Penerapan Model Multinomial Logistik Dalam Memprediksi Intensi Berwirausaha Mahasiswa
}

\author{
Triska Dewi Pramitasari ${ }^{1}$, Ratnaning Tyasasih ${ }^{2}$ \\ 1,2, Universitas Abdurachman Saleh Situbondo

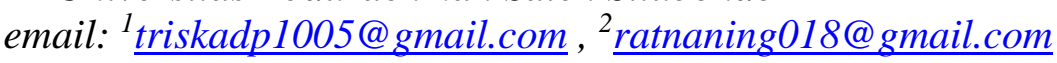

\section{Artikel History:}

Artikel masuk : 07-11-2019

Artikel revisi : 03-02-2020

Artikel diterima : 04-05-2020

Keywords:

Manajemen Keuangan Pribadi, Efikasi Diri, Parental, Pendidikan

Kewirausahaan,E-commerce,

Intensi Berwirausaha.

\begin{abstract}
ABSTRAK
Tujuan penelitian ini adalah untuk menganalisa bagaimana penggunaan manajemen keuangan pribadi, efikasi diri, parental, pendidikan kewirausahaan dan e-commerce dalam memprediksi intensi berwirausaha. Populasi dari penelitian ini merupakan seluruh mahasiswa Prodi Manajemen Fakultas Ekonomi UNARS yang telah menempuh mata kuliah Kewirausahaan (I dan II) sebanyak 211 mahasiswa. Teknik pengambilan sampel menggunakan simple random sampling, dimana penentuan jumlah sampel menggunakan model Slovin sehingga ditemukan jumlah sampel sebanyak 68 mahasiswa. Teknik analisa data menggunakan analisis multinomial logistik untuk mengetahui manakah dari kelima variabel independen yang dapat digunakan untuk memprediksi intensi berwirausaha mahasiswa. Hasil penelitian ini menyimpulkan bahwa manajemen keuangan pribadi, efikasi diri dan pendidikan kewirausahaan secara konsisten dapat digunakan untuk memprediksi intensi berwirausaha kategori sedang dan besar. Parental hanya dapat digunakan untuk memprediksi intensi berwirausaha kategori sedang. Sedangkan e-commerce hanya dapat digunakan untuk memprediksi intensi berwirausaha kategori besar.
\end{abstract}

\section{ABSTRACT}

The purpose of this study is to analyze how the use of personal financial management, self-efficacy, parental, entrepreneurship education and e-commerce in predicting entrepreneurial intentions. The population of this study were all students of Management Study Program at the Faculty of Economics UNARS who had taken Entrepreneurship courses (I and II) totaling 211 students. The sampling technique uses simple random sampling, where the determination of the number of samples using the Slovin model so that a total sample of 68 students was found. The data analysis technique uses logistic multinomial analysis to find out which of the five independent variables can be used to predict student entrepreneurship intentions. The results of this study conclude that personal financial management, self-efficacy and entrepreneurship education can consistently be used to predict the intentions of medium and large categories of entrepreneurship. Parental can only be used to predict entrepreneurial intentions of 
the medium category. Whereas e-commerce can only be used to predict the intention of a large category of entrepreneurship

\section{PENDAHULUAN}

Salah satu tantangan yang dihadapi oleh suatu negara, khususnya Indonesia yaitu mengatasi masalah pengangguran. Menurut data dari BPS yang diupdate pada tanggal 23 Januari 2019 menunjukkan bahwa tingkat pengangguran dari kalangan terdidik masih cukup tinggi. Lulusan dari perguruan tinggi selama 3 tahun terakhir terus mengalami peningkatan. Pada Agustus 2018 lulusan dari perguruan tinggi menyumbangkan 10,42 \% pengangguran dari total pengangguran yang ada di Indonesia. Hal tersebut menunjukkan bahwa lulusan dari perguruan tinggi tidak menjamin bahwa seseorang akan mudah dalam memperoleh pekerjaan. Oleh karena itu diperlukan upaya peningkatan intensi wirausaha di kalangan mahasiswa. Minat berwirausaha dipengaruhi oleh beberapa faktor diantaranya manajemen keuangan pribadi, efikasi diri, parental, pendidikan kewirausahaan dan $e$-commerce.

Manajemen keuangan pribadi dapat memicu intensi berwirausaha karena adanya faktor tabungan dan investasi (Kotze dan Smit, 2008:10). Ketika seseorang mampu mengelola keuangan pribadinya secara benar yang terlihat dalam keteraturan menabung, maka hal tersebut akan memudahkan orang tersebut untuk memulai berwirausaha karena adanya modal usaha.

Faktor kedua adalah masalah efikasi diri yang tinggi (faktor personality) yang ikut berkontribusi terhadap kesuksesan seseorang dalam berwirausaha. Flavius (2007:107) menyatakan bahwa tingkat efikasi diri seseorang dapat menunjukkan proses pemilihan dan penyesuaian diri terhadap pilihan karir dalam hidupnya.

Parental (lingkungan keluarga) adalah komponen dasar bagi tumbuh dan kembangnya seorang anak. Hal ini memberikan pengaruh awal terhadap terbentuknya kepribadian. Dari hasil penelitiannya, Suhartini (2011) menyatakan lingkungan keluarga berpengaruh terhadap minat berwirausaha. Semakin kondusif kondisi lingkungan keluarga di sekitarnya, akan semakin mendorong seseorang untuk menjadi wirausahawan.

Pendidikan kewirausahaan tidak hanya sebatas memberikan landasan teori tentang konsep kewirausahaan tetapi juga membentuk sikap, perilaku, dan pola pikir (mindset) seorang wirausahawan (entrepreneur). Ini menjadi modal awal seseorang untuk mempersiapkan diri dalam memulai bisnisnya melalui pengalaman, keterampilan, dan pengetahuan untuk mengembangkan dan memperluas bisnisnya kelak.

E-Commerce memberikan peluang besar bagi setiap orang berbisnis karena mampu menciptakan bisnis dalam dunia maya yang mampu menghubungkan orang-orang secara luas tanpa batasan geografis. Dengan adanya $e$-commerce seperti web atau media elektronik lainnya 
diharapkan dapat berpengaruh terhadap calon wirausahawan yang ingin berbisnis namun memiliki modal kecil.

Penelitian seperti ini telah dilakukan oleh beberapa peneliti sebelumnya, baik di Indonesia maupun di luar negeri. Penelitian-penelitian tesebut mengemukakan adalah research gap tentang faktor-faktor yang dapat digunakan dalam memprediksi intensi berwirausaha mahasiswa, diantaranya anatara penelitian Sumarsono (2013), penelitian Santoso (2016), penelitian Palupi (2015) dan penelitian Supriyanto dan Meilita (2017).

Bukti-bukti empiris diatas, hasil dari penelitian yang belum konsisten menimbulkan pertanyaan menarik, apakah manajemen keuangan pribadi, efikasi diri, parental, pendidikan kewirausahaan dan e-commerce dapat digunakan untuk memprediksi intensi berwirausaha mahasiswa. Berdasarkan penjelasan tersebut, maka penelitian ini mengambil judul "Penerapan Model Multinomial Logistik dalam Memprediksi Intensi Berwirausaha Mahasiswa". Adapun tujuan yang ingin dicapai dalam penelitian adalah untuk menganalisis penggunaan manajemen keuangan pribadi, efikasi diri, parental, pendidikan kewirausahaan dan e-commerce untuk memprediksi intensi berwirausaha

\section{TINJAUAN PUSTAKA}

\section{Intensi Berwirausaha}

Intensi berwirausaha menjembatani antara sikap seseorang terhadap kewirausahaan dengan perilaku kewirausahaannya, sehingga niat berwirausaha merupakan variabel tepat untuk memprediksi perilaku kewirausahaannya. Intensi berwirausaha merupakan kebulatan tekad seseorang untuk menjadi seorang wirausaha atau untuk berwirausaha. Berdasarkan uraian tersebut, intensi berwirausaha dapat diartikan sebagai kebulatan tekad seseorang untuk memulai berwirausaha. Intensi berwirausaha merupakan faktor penting untuk menumbuhkan perilaku kewirausahaan sehingga dalam pembelajaran mengenai kewirausahaan, sangat penting untuk meningkatkan niat berwirausaha mahasiswa.

\section{Manajemen Keuangan Pribadi}

Menurut Gitman (2012) manajemen keuangan pribadi merupakan seni dan ilmu mengelola sumber daya (money) dari unit individual / rumah tangga. Dalam proses pengelolaannya tidak mudah untuk mengaplikasikannya karena terdapat beberapa langkah sistematis yang harus diikuti. Namun dengan mengetahui manajemen keuangan pribadi, merupakan langkah awal untuk penerapan yang tepat ketika seseorang mengelola uang 
pribadinya. Hal ini didasari oleh sebuah alasan bahwa segala sesuatu diawali dari kepala, berpikir dahulu baru bertindak.

\section{Efikasi Diri}

Menurut Luthans (2008:205) efikasi diri mampu mendorong kinerja seseorang dalam berbagai bidang termasuk dalam hal minat berwirausaha. Oleh karena itu, dalam mendirikan usaha diperlukan adanya keyakinan diri (self-efficacy) terhadap kemampuan yang dimiki agar usahanya dapat berhasil. Hal yang sama juga diungkapkan oleh Robbins (2007:180). Dalam hal ini efikasi diri juga dikenal sebagai teori kognitif sosial/penalaran sosial yang mengarah pada keyakinan seseorang akan kemampuannya dalam menjalankan suatu tugas. Dari penjelasan yang telah disampaikan di atas, maka dapat disimpulkan bahwa efikasi diri merupakan keyakinan diri seseorang pada kemampuannya untuk mencapai tujuan tertentu.

\section{Parental}

Parental (lingkungan keluarga) merupakan kelompok masyarakat terkecil yang terdiri atas ayah, ibu, anak serta anggota keluarga lainnya. Keluarga merupakan peletak dasar bagi tumbuh dan berkembangnya anak yang memberikan pengaruh awal terhadap terbentuknya kepribadian seseorang. Orang tua yang berwirausaha di bidang tertentu dapat mempengaruhi minat anaknya untuk juga ikut berwirausaha (Suhartini, 2011).

\section{Pendidikan Kewirausahaan}

Pendidikan kewirausahaan merupakan proses pendidikan yang menerapkan prinsip dan metode kearah pembentukan kecakapan hidup (life skill) pada peserta didiknya melalui kurikulum terintegrasi yang dikembangkan disekolah maupun diperguruan tinggi. (Widiyatnoto, 2013:5). Pendidikan kewirausahaan akan mempengaruhi hasrat, jiwa dan perilaku seorang wirausaha. Pengetahuan, keterampilan serta kemampuan kerja yang dimiliki oleh peserta dapat mendorong tumbuhnya minat untuk berwirausaha, serta merupakan modal dasar yang dapat digunakan untuk berwirausaha nantinya.

\section{E-Commerce}

E-Commerce (Electronic Commerce) merupakan suatu proses transakasi jual beli yang menggunakan alat elektronik seperti telepon dan internet. E-commerce lebih dari sekedar jual beli produk secara online. Sistem e-commerce sangat bergantung pada penggunaan internet dan IT lainnya untuk mendukung setiap prosesnya. (Mujiyana : 2013). Sehingga dapat dijelaskan bahwa e-commerce dapat membantu penjual dalam mempromosikan barangnya secara online karena dengan adanya e-commerce memberikan banyak kemudahan bagi calon konsumen 
untuk membeli barang yang diinginkannya dengan memanfaatkan semua fasilitas yang telah ada.

\section{Pengembangan Hipotesis}

\section{Hubungan antara manajemen keuangan pribadi dengan intensi berwirausaha}

Manajemen keuangan pribadi mampu meningkatkan intensi berwirausaha karena terdapat faktor tabungan dan investasi. Disaat seseorang telah mampu mengelola keuangan pribadinya secara benar yang terlihat dalam keteraturannya disaat menabung, maka akan memudahkan orang tersebut untuk memulai berwirausaha karena telah memiliki modal usaha. Semakin baik seseorang menghindarkan diri dari utang, maka akan semakin bagus dalam mengakumulasi modal usahanya. Dengan modal tersebut, tentunya akan mendorong niat seseorang untuk mengakumulasikan uangnya melalui kegiatan berwirausaha. (Kotze dan Smit, 2008:10). Hal tersebut sejalan dengan hasil penelitian Sina (2013), Nurfaizana (2017) dan Pramitasari (2018) yang menjelaskan bahwa manajemen keuangan pribadi memiliki pengaruh positif dan signifikan terhadap intensi berwirausaha.

$\mathrm{H}_{1}$ : Manajemen keuangan pribadi dapat digunakan untuk memprediksi intensi berwirausaha

\section{Hubungan antara efikasi diri dengan intensi berwirausaha}

Keputusan berwirausaha adalah sebuah perilaku dengan keterlibatan tinggi (high involvement) karena dalam mengambil keputusannya akan melibatkan faktor kepercayaan pada kemampuan diri sendiri (self efficacy), bersikap positif (sikap berperilaku) serta dukungan lingkungan (norma subyektif) (Widayoko, 2016 : 6). Seorang yang memiliki efikasi diri tinggi cenderung akan lebih berani untuk berwirausaha. Efikasi diri yang tinggi menuntut seseorang untuk memiliki rasa kepercayaan diri, sabar, tidak mudah menyerah serta berani menanggung risiko. Hal tersebut sejalan dengan hasil penelitian Nurhidayah (2014), Nurfaizana (2017) dan Pramitasari (2018) yang menunjukkan bahwa efikasi diri memiliki pengaruh positif dan signifikan terhadap intensi berwirausaha.

$\mathrm{H}_{2}$ ： Efikasi diri dapat digunakan untuk memprediksi intensi berwirausaha

\section{Hubungan antara parental dengan intensi berwirausaha}

Lingkungan keluarga mempengaruhi minat berwirausaha seseorang. Semakin kondusif lingkungan keluarga di sekitarnya, semakin mendorong seseorang untuk menjadi seorang wirausahawan. Disaat lingkungan keluarga mendukung, akan semakin tinggi niat seseorang untuk menjadi wirausahawan dibandingkan disaat tidak memiliki dukungan dari lingkungan keluarga (Suhartini:2011). Hal tersebut sejalan dengan hasil penelitian Santosa (2016) dan Dusak dan Sudiksa (2016) yang menunjukkan bahwa parental (lingkungan keluarga) memiliki pengaruh positif dan signifikan terhadap intensi berwirausaha. 
$\mathrm{H}_{3}$ : Parental dapat digunakan untuk memprediksi intensi berwirausaha

\section{Hubungan antara pendidikan kewirausahaan dengan intensi berwirausaha}

Penyerapan proses pembelajaran kewirausahaan yang baik akan dapat mempengaruhi tingginya tingkat intensi berwirausaha pada mahasiswa. Nursito dan Nugroho (2013), menyatakan bahwa pendidikan kewirausahan mempunyai peranan yang sangat penting dalam kegiatan kewirausahaan. Menurut Suharti dan Sirine (2011) salah satu faktor pendorong pertumbuhan kewirausahaan disuatu negara terletak pada peranan perguruan tinggi melalui penyelenggaraan pendidikan kewirausahaan. Lestari dan Wijaya (2012) menyatakan bahwa pendidikan kewirausahaan dapat membentuk pola pikir, sikap serta perilaku pada mahasiswa untuk menjadi seorang wirausahawan sejati sehingga nantinya akan mampu mengarahkan untuk memilih berwirausaha sebagai pilihan karir mereka. Hal tersebut sejalan dengan hasil penelitian Santosa (2016), Dusak dan Sudiksa (2016) dan Susanto (2017) yang menunjukkan bahwa pendidikan kewirausahaan memiliki pengaruh positif dan signifikan terhadap intensi berwirausaha.

$\mathrm{H}_{4}$ : Pendidikan kewirausahaan dapat digunakan untuk memprediksi intensi berwirausaha

\section{Hubungan antara e-commerce dengan intensi berwirausaha}

Dengan adanya perkembangan e-commerce, mahasiswa akan semakin dimudahkan dalam menyelesaikan semua tugas, khususnya yang berhubungan dengan $e$-commerce sehingga mahasiswa nantinya akan lebih menguasai matakuliah kewirausahaan. Diharapkan setelah lulus nantinya mahasiswa akan mampu mengaplikasikan ilmu yang telah di peroleh selama di bangku perkuliahan. Penerapan e-commerce mempunyai pengaruh positif dan signifikan terhadap kinerja individu dalam mempeluas pemasaran usaha. Selain itu, manfaat yang diperoleh dengan diterapkannya e-commerce dapat menjangkau biaya komunikasi antara pemilik usaha dan konsumen yang lebih cepat, murah serta dapat berperan penting dalam pengambilan keputusan untuk berwirausaha (Sutikno et al, 2012). Hal tersebut sejalan dengan hasil penelitian Yadewani dan Wijaya (2017) dan Pramiswari dan Dharmadiaksa (2017) serta Sari dan Wibawa (2017) yang menunjukkan bahwa e-commerce memiliki pengaruh positif dan signifikan terhadap intensi berwirausaha.

$\mathrm{H}_{5} \quad$ : $\quad$-commerce dapat digunakan untuk memprediksi intensi berwirausaha

\section{METODE PENELITIAN}

Data dalam penelitian ini adalah data primer yang diperoleh langsung dari responden. Adapun jenis data yang digunakan dalam penelitian ini merupakan hasil dari pengisian kuesioner yang dilakukan oleh responden mengenai identitas responden dan tanggapan 
responden yang berhubungan dengan variabel yang digunakan dalam memprediksi intensi berwirausaha.

Populasi yang digunakan adalah seluruh mahasiswa Prodi Manajemen FE UNARS yang telah menempuh mata kuliah Kewirausahaan (I dan II) berjumlah 211 mahasiswa. Teknik pengambilan sampel yang digunakan adalah simple random sampling, dengan menggunakan model Slovin (Tejada dan Punzalan, 2012) sehingga diperoleh jumlah sampel sebanyak 68 mahasiswa.

Metode analisa data dalam penelitian ini menggunakan beberapa metode pengujian diantaranya uji instrumen (uji validitas dan reabilitas), uji normalitas data, analisis multinomial logistik, uji asumsi klasik serta uji parameter model. Uji validitas dipakai untuk mengukur valid tidaknya suatu kuesioner. Dianggap valid apabila memenuhi KMO > 0,5 dan loading factor (component matrix) memenuhi kaidah pengujian, yaitu > 0,4 (Ghozali,2016). Uji reabilitas dipakai untuk mengukur kuesioner yang menjadi alat pengukuran variabel. Suatu instrumen dikatakan reliabel apabila nilai Conbrach Alpha > 0.6 (Ghozali 2016). Uji normalitas data dilakukan untuk menguji apakah di dalam model regresi, variabel dependen dan independen berdistribusi normal. Uji normalitas data ditentukan dengan melakukan uji statistik nonparametrik Kolmogorov-Smirnov (K-S). Salah satu alternatif yang dapat digunakan dalam mengatasi masalah data yang tidak berdistribusi normal adalah dengan cara mentransformasikan data dalam bentuk z-score. (Ghozali, 2016:41). Variabel terikat lebih dari 2 kategori yaitu intensi berwirausaha kategori kecil, sedang dan besar, teknik statistik yang dianggap mampu mengakomodir persoalan itu adalah model multinomial logistik. Tujuan dari pengujian asumsi klasik yaitu untuk memberikan kepastian tentang persamaan regresi yang diperoleh memiliki ketepatan dalam estimasi, konsisten dan tidak bias. Model logistik tidak mensyaratkan harus berdistribusi normal serta memiliki asumsi linierity dan homogenitas, sehingga tidak melakukan uji normalitas, autokorelasi, linieritas, serta heteroskedastisitas. Sedangkan uji multikolinieritas, dikarenakan hanya melibatkan variabel independen, maka masih perlu untuk dilakukan pengujian. (Hosmer, 2000:90-106). Dan uji yang terakhir adalah uji parameter model yang terdiri dari tiga tahapan yaitu uji serentak, uji parsial serta uji kesesuaian model.

\section{HASIL \& PEMBAHASAN}

\section{Hasil Penelitian}

\section{Uji Instrumen Data}

Hasil uji validitas menunjukkan bahwa nilai KMO untuk seluruh variabel berada pada posisi diatas angka 0,5 (cut-off) sehingga seluruh variabel di atas dinyatakan valid. Sedangkan 
hasil uji reabilitas menunjukkan bahwa nilai Cronbach's Alpha seluruh variabel $>0,6$ dan probabilitas sig $\mathrm{F}<0,05$ yang menjelaskan bahwa seluruh variabel dinyatakan reliabel.

\section{Uji Normalitas Data}

Hasil dari uji normalitas data menunjukkan bahwa terdapat tiga variabel (manajemen keuangan pribadi, parental dan intensi berwirausaha) yang memiliki nilai signifikansi $>\alpha$, sehingga Ho diterima dimana artinya data berdistribusi normal. Namun tiga variabel lain (efikasi diri, pendidikan kewirausahaan dan e-commerce) menunjukkan data berdistribusi tidak normal sehingga Ho ditolak. Alternatif yang digunakan adalah mentransformasi data kedalam bentuk z-score sehingga menciptakan keseluruhan data berdistribusi normal.

\section{Analisis Multinomial Logistik}

Pengolahan data dalam analisis multinomial logistik memiliki 3 tahapan yaitu estimasi parameter pada model, uji kebaikan model serta validasi model.

\section{a. Estimasi Parameter Model}

Hal ini dilakukan dalam rangka memperoleh nilai konstanta dan koefisien pada model. Hasil estimasi parameter model dijelaskan pada tabel 1.

Tabel 1. Hasil Estimasi Parameter Model

\begin{tabular}{llrlr}
\hline & INSD & \multicolumn{1}{c}{ B } & Sig. & Exp(B) \\
\hline \multirow{6}{*}{ Sedang } & Intercept & 26,568 & 0,000 & \\
& Z-Mnj Keu Pribadi & 15,755 & $0,041^{* *}$ & 6,953 \\
& Z-Efikasi Diri & 0,499 & $0,012^{* *}$ & 0,607 \\
& Z-Parental & 102,401 & $0,041^{* *}$ & 2,965 \\
& Z-Pend & 10,252 & $0,010^{* *}$ & 3,530 \\
& Kewirausahaan & 82,183 & $0,775^{\mathrm{TS}}$ & 2,034 \\
& Z-E-Commerce & 29,615 & 0,000 & \\
& Intercept & 86,887 & $0,001^{* * *}$ & 5,428 \\
& Z-Mnj Keu Pribadi & 5,283 & $0,003^{* * *}$ & 196,914 \\
& Z-Efikasi Diri & $-32,513$ & $0,276^{\mathrm{TS}}$ & 7,58 \\
& Z-Parental & 22,209 & $0,043^{* *}$ & 2,26 \\
& Z-Pend & 53,571 & $0,039^{* *}$ & 1,843 \\
\hline & Kewirausahaan & & & \\
& Z-E-Commerce & & &
\end{tabular}

Keterangan :

$* * *$ sig. $1 \%, * *$ sig. $5 \%, *$ sig. $10 \%$, TS tdk sig

Sumber : hasil yang diolah, 2019 


\section{b. Uji Kebaikan Model}

Nilai koefisien Negelkerke sebesar 0,97, sehingga dapat diartikan 97,9\% prediksi intensi berwirausaha mahasiswa dapat dijelaskan oleh Manajemen Keu Pribadi, Efikasi Diri, Parental, Pendidikan Kewirausahaan dan E-Commerce. Dan sisanya sebesar 2,1\% prediksi intensi berwirausaha dijelaskan oleh variabel lain yang tidak terdapat dalam penelitian ini.

\section{Uji Multikoleniaritas}

Hasil uji multikoleniaritas menjelaskan bahwa seluruh koefisien korelasi < 0,9. Hal ini menunjukkan bahwa tidak ada masalah multikolinearitas diantara variabel penjelas yang telah dipakai dalam model.

\section{Uji Parameter Model}

Hasil perhitungan uji rasio likelihood menghasilkan Chi-Square sebesar 120,225 dengan nilai sig $(0,000)<\alpha$ sehingga $\mathrm{H}_{0}$ ditolak (terdapat paling tidak 1 variabel prediktor yang mampu memprediksi intensi berwirausaha)

Hasil perhitungan uji wald menjelaskan pada model pertama terdapat satu variabel independen yaitu Z-E-Commerce yang memiliki nilai sig $>\alpha$ sehingga $\mathrm{H}_{0}$ diterima (variabel prediktor tidak mampu memprediksi intensi berwirausahan kategori sedang). Sedangkan 4 variabel lainnya (Z-Mnj Keu Pribadi, Z-Efikasi Diri, Z-Parental dan Z-Pendidikan Kewirausahaan) menolak $\mathrm{H}_{0}$ (variabel prediktor mampu memprediksi kepemilikan manajerial kategori sedang). Hasil perhitungan uji wald menjelaskan pada model kedua terdapat satu variabel independen yaitu Z-Parental yang memiliki nilai sig $>\alpha$ sehingga $\mathrm{H}_{0}$ diterima (variabel prediktor tidak mampu memprediksi intensi berwirausahan kategori besar). Sedangkan 4 variabel lainnya (Z-Mnj Keu Pribadi, Z-Efikasi Diri, Z-Pendidikan Kewirausahaan dan Z-ECommerce ) menolak $\mathrm{H}_{0}$ (variabel prediktor mampu memprediksi kepemilikan manajerial kategori besar).

Hasil dari uji Chi-Square menunjukkan bahwa nilai signifikan koefisien Pearson dan Deviance $>$ level signifikansi $(\alpha)$, yang berarti $\mathrm{H}_{0}$ diterima. Ini mengindikasikan bahwa model layak digunakan pada analisis selanjutnya.

\section{Pembahasan}

\section{Penggunaan Manajemen Keuangan Pribadi untuk Memprediksi Intensi Berwirausaha}

Hasil analisis menunjukkan bahwa pada persamaan pertama maupun kedua koefisien Zmanajemen keuangan pribadi memiliki parameter positif dan signifikan, yang berarti semakin tinggi nilai manajemen keuangan pribadi maka semakin tinggi probabilitas mahasiswa yang diklasifikasikan memiliki intensi berwirausaha kategori sedang maupun besar. Hasil ini 
konsisten dengan hasil penelitian Nurfaizana dan Andayani (2017) dan Pramitasari dan
Tyasasih (2019) yang menjelaskan bahwa manajemen keuangan pribadi secara statistik berpengaruh positif signifikan terhadap intensi berwirausaha. Namun hasil penelitian ini tidak konsisten dengan hasil penelitian Puspitaningtyas (2017) yang menunjukkan bahwa manajemen keuangan pribadi mempunyai parameter positif dan tidak signifikan. Perbedaan hasil penelitian ini terjadi karena pada penelitian ini mahasiswa cenderung hemat dimana terlihat dari teraturnya mereka dalam menabung serta mengakumulasikannya menjadi sebuah modal untuk rencana usaha diwaktu yang akan datang. Hal ini tentunya akan memberikan peluang untuk memicu intensi berwirausaha yang tinggi.

\section{Penggunaan Efikasi Diri untuk Memprediksi Intensi Berwirausaha}

Hasil analisis menunjukkan bahwa pada persamaan pertama maupun kedua koefisien Zefikasi diri memiliki parameter positif dan signifikan, yang berarti semakin tinggi nilai efikasi diri maka semakin tinggi probabilitas mahasiswa yang diklasifikasikan memiliki intensi berwirausaha kategori sedang maupun besar. Hasil ini konsisten dengan hasil penelitian Sumarsono (2013), Nurfaizana dan Andayani (2017), Pamungkas (2017), Pramitasari (2018), dan Kamil (2018) yang menjelaskan bahwa efikasi diri secara statistik berpengaruh positif signifikan terhadap intensi berwirausaha. Efikasi diri menjadi salah satu faktor internal yang mampu memprediksi minat berwirausaha. Agar tercapai efikasi diri yang tinggi, mahasiswa harus memiliki keyakinan akan kemampuan dalam mengatasi segala kesulitan.

\section{Penggunaan Parental untuk Memprediksi Intensi Berwirausaha}

Hasil analisis menunjukkan bahwa pada persamaan pertama koefisien Z-parental memiliki parameter positif dan signifikan yang berarti semakin tinggi nilai parental maka semakin tinggi probabilitas mahasiswa yang diklasifikasikan memiliki intensi berwirausaha kategori sedang. Hasil ini konsisten dengan hasil penelitian Dusak dan Sudiksa (2016), Wijayanti dan Suryani (2016), Yusuf, Natsir dan Kornelius (2017), Supeni dan Efendi (2017) serta Kamil (2018) yang menjelaskan bahwa parental secara statistik berpengaruh positif signifikan terhadap intensi berwirausaha. Sedangkan pada persamaan kedua menunjukkan bahwa Koefisien Z-parental memiliki parameter negatif dan tidak signifikan yang berarti tidak dapat memprediksi probabilitas mahasiswa yang diklasifikasikan memiliki intensi berwirausaha kategori besar. Hasil ini konsisten dengan hasil penelitian Sumarsono (2013), yang menunjukkan bahwa parental memiliki parameter positif dan tidak signifikan. Perbedaan hasil penelitian ini dikarenakan pada penelitian ini mahasiswa dengan pekerjaan orang tua sebagai wiraswasta (memiliki usaha) cenderung akan memiliki niat untuk berwirausaha yang lebih tinggi dibandingkan mahasiswa dengan pekerjaan orang tua non wiraswasta. 


\section{Penggunaan Pendidikan Kewirausahaan untuk Memprediksi Intensi Berwirausaha}

Hasil analisis menunjukkan bahwa pada persamaan pertama dan kedua koefisien Zpendidikan kewirausahaan memiliki parameter positif dan signifikan yang berarti semakin tinggi nilai pendidikan kewirausahaan maka semakin tinggi probabilitas mahasiswa yang diklasifikasikan memiliki intensi berwirausaha kategori sedang maupun besar. Hasil ini konsisten dengan hasil penelitian Dusak dan Sudiksa (2016), Rembulan dan Fensi (2017), Supeni dan Efendi (2017), dan Pamungkas (2017) yang menjelaskan bahwa pendidikan kewirausahaan memiliki pengaruh positif dan signifikan terhadap intensi berwirausaha. Namun hasil penelitian ini tidak konsisten dengan hasil penelitian Haryono (2018) yang menunjukkan bahwa pendidikan kewirausahaan memiliki parameter positif dan tidak signifikan. Perbedaan hasil penelitian ini dikarenakan pada penelitian ini kurikulum pendidikan kewirusahaan pada FE UNARS memang sudah cukup lengkap, karena selain mengajarkan teori, mahasiswa juga diberi kesempatan untuk mempraktekkannya lansung baik berupa tugas selama perkuliahan maupun dalam ekstrakulikuler yang disediakan oleh Universitas. Hal ini dibuktikan dengan hasil jawaban dari responden pada kuesioner bagian pendidikan kewirausahaan dengan indeks persentase sebanyak 85\%, di samping itu kondisi lingkungan di FE yang sudah cukup mendukung untuk menciptakan stimulus dalam menumbuhkan minat berwirausaha, seperti ketersediaan sarana dan prasarana, ditambah lagi perbincangan-perbincangan mengenai berwirausaha atau kewirausahaan di kalangan mahasiswa FE UNARS itu sudah sangat banyak.

\section{Penggunaan E-Commerce untuk Memprediksi Intensi Berwirausaha}

Hasil analisis menunjukkan bahwa pada persamaan pertama koefisien Z-e-commerce kewirausahaan memiliki parameter positif dan tidak signifikan, yang berarti e-commerce tidak dapat memprediksi probabilitas mahasiswa yang diklasifikasikan memiliki intensi berwirausaha kategori sedang. Persamaan kedua menunjukkan bahwa koefisien Z-e-commerce diri memiliki parameter positif dan signifikan, yang berarti semakin tinggi nilai e-commerce maka semakin tinggi probabilitas mahasiswa yang diklasifikasikan memiliki intensi berwirausaha kategori besar. Hasil ini konsisten dengan hasil penelitian Pramiswari dan Dharmadiaksa (2017), Yadewani dan Wijaya (2017) serta Sari dan Wibawa (2017) yang menjelaskan bahwa e-commerce berpengaruh positif dan signifikan terhadap minat berwirausaha. Dengan adanya perkembangan e-commerce, mahasiswa akan semakin dimudahkan dalam menyelesaikan semua tugas, khususnya yang berhubungan dengan $e$ commerce sehingga mahasiswa nantinya akan lebih menguasai matakuliah kewirausahaan. Diharapkan setelah lulus nantinya mahasiswa akan mampu mengaplikasikan ilmu yang telah di peroleh selama di bangku perkuliahan. 


\section{Hasil Prediksi Analisis Multinomial Logistik}

Kelompok 1, 2 dan 3 (kategori kecil, sedang dan besar) secara berturut-turut memiliki persentase kebenaran sebesar 100,0\%, 93,8\% dan 97,6\%. Hal ini mengindikasikan bahwa kelompok 1, 2 dan 3 memiliki daya klasifikasi nyata / bermanfaat (a useful model) dikarenakan nilai persentase kebenaran > overall percentage accuracy rate. Persentase daya klasifikasi model secara menyeluruh (overall percentage classification) yaitu sebesar 97,1\%. Sehingga dapat disimpulkan bahwa model yang dibentuk memiliki daya klasifikasi nyata / bermanfaat ( $a$ useful model) dikarenakan nilai klasifikasi secara keseluruhan (overall percentage classification) $>$ overall percentage accuracy rate. Hasil prediksi intensi berwirausaha pada penelitian ini lebih baik daripada tiga penelitian sebelumnya, yaitu penelitian Rosyidah, Iffatur (2017) sebesar 63,2\%, penelitian Hirlan Khaeri dan Gandhi Pawitan (2018) sebesar 79,9\% serta penelitian Haris Mahmudi, Agus Tjahjono and Zainal Abidin (2017) sebesar 90\%. Tingginya hasil persentase daya klasifikasi model keseluruhan (overall percentage classification) pada penelitian ini dikarenakan persentase kebenaran seluruh kelompok (kecil, sedang, besar) yang sangat tinggi yaitu mencapai $100 \%, 93,8 \%$ dan 97,6\%. Hal ini berhubungan dengan hasil uji kebaikan model dimana nilai koefisien Negelkerke sebesar 0,979 atau 97,9\%. Variabel independen pada penelitian ini sudah mampu menjelaskan prediksi intensi berwirausaha sebesar $97,9 \%$. Sedangkan sisanya hanya sebesar $2,1 \%$ prediksi intensi berwirausaha dijelaskan oleh variabel lain yang tidak termasuk pada penelitian ini.

\section{SIMPULAN \& SARAN}

Manajemen keuangan pribadi, efikasi diri dan pendidikan kewirausahaan secara konsisten dapat digunakan dalam memprediksi intensi berwirausaha, dimana peningkatan nilai manajemen keuangan pribadi, efikasi diri dan pendidikan kewirausahaan cenderung lebih besar mempengaruhi prediksi intensi berwirausaha kategori sedang dan besar dibandingkan dengan kategori kecil. Parental dapat digunakan dalam memprediksi intensi berwirausaha kategori sedang, namun tidak dapat digunakan dalam memprediksi intensi berwirausaha kategori besar. Dan e-commerce tidak dapat digunakan dalam memprediksi intensi berwirausaha kategori sedang, namun dapat digunakan untuk memprediksi intensi berwirausaha, dimana peningkatan nilai e-commerce cenderung lebih besar mempengaruhi prediksi intensi berwirausaha kategori besar dibandingkan dengan kategori kecil.

Adapun keterbatasan dari penelitian ini adalah dimana nilai Pseudo R2 hanya sebesar $97,9 \%$, berarti terdapat sekitar $2,1 \%$ variabel di luar penelitian yang dapat memprediksi intensi berwirausaha pada mahasiswa selama periode penelitian. Oleh karena itu penelitian selanjutnya 
dapat memakai variabel lain yang mampu memprediksi intensi berwirausaha, seperti locus of control, latar belakang pendidikan, pelatihan, gender, usia, kebutuhan akan berprestasi, kemandirian, toleransi keambiguan dll. Sehingga diharapkan mampu memperoleh nilai prediksi yang lebih akurat. Terakhir, penulis ingin mengucapkan terima kasih kepada Ristekdikti perihal pendanaan yang telah diberikan untuk penelitian ini.

\section{DAFTAR PUSTAKA}

Badan Pusat Statistik, 2019, Pengangguran Terbuka Menurut Pendidikan Tertinggi yang Ditamatkan 1986 - 2018, viewed 25 Mei 2019, ( http://www.bps.go.id/ ).

Dusak, I Kade Aris Friatnawan dan Sudiksa, Ida Bagus. 2016. Pengaruh Pendidikan Kewirausahaan, Parental, Dan Locus Of Control Terhadap Niat Berwirausaha Mahasiswa. E-Jurnal Manajemen Unud, Vol. 5, No.8, 2016: 5184-5214

Flavius, M.W. Gerhardt \& J.R Kickul. 2007. The Role of Cognitive Style and Risk Preference on Entrepeneur self-efficacy and Entrepeneurial Intentions. Journal of Leadership and Organizational Studies, 3 (4), pp :107-110

Ghozali, I., 2016. Aplikasi Analisis Multivariete Dengan Program IBM SPSS 23. Badan Penerbit Universitas Diponegoro : Semarang.

Gitman, L. J., 2012. Principles Of Managerial finance. 13th Edition. Pearson Education, Inc : United States.

Hosmer, D.W., \& S. Lemeshow., 2000. Applied Logistic Regression. Second Edition, John Willey \& Sons : New York.

Kotzé, L., \& Smit, A. 2008. Personal financial literacy and personal debt management: the potential relationship with new venture creation. The Southern African Journal of Entrepreneurship and Small Business Management, 1(1), 35-50. DOI: https://doi.org/10.4102/sajesbm.v1i1.11

Lestari, R. B., \& Wijaya, T. 2012. Pengaruh pendidikan kewirausahaan terhadap minat berwirausaha mahasiswa di STIE MDP, STMIK MDP, dan STIE MUSI. Jurnal Penelitian STIE MDP.

Luthans, Fred. 2008. Organizational Behavior. Singapura: The McGraw Hill Companies.Inc.

Mujiyana dan Ingge. 2013. Analisis Faktor- Faktor yang Mempengaruhi Keputusan Pembelian Via Internet Pada Toko Online. Jurnal Jati Undip, 8(3). 143- 152.

Nurfaizana, D.R., \& Andayani, E., 2017. Pengaruh Manajemen Keuangan Pribadi dan Efikasi Diri terhadap Intensi Berwirausaha Mahasiswa Pendidikan Ekonomi. Seminar Nasional \& Call For Paper, FEB Unikama "Peningkatan Ketahanan Ekonomi Nasional dalam Rangka Menghadapi Persaingan Global”, 414-421. Malang.

Nurhidayah. 2014. Pengaruh Efikasi diri terhadap Intensi Berwirausaha Mahasiswa Program Studi Pendidikan Administrasi Perkantoran angkatan 2010-2012 FE UNY. Skripsi. Yogyakarta: ejournal.uny.ac.id.

Nursito, S., \& Nugroho, A. J. 2013. Analisis pengaruh interaksi pengetahuan kewirausahaan dan efikasi diri terhadap intensi kewirausahaan. Kiat Bisnis.

Palupi, D. 2016. Pengaruh Adversity Quotiont Dan Pendidikan Kewirausahaan Terhadap Minat Berwirausaha Mahasiswa. Kompetensi (Competence: Journal of Management Studies), 9(2).

Pramiswari, Dewa Ayu Anggi dan Ida Bagus Dharmadiaksa. 2017. Pengaruh E-Commerce Dan Penggunaan Sistem Informasi Akuntansi Dalam Pengambilan Keputusan Untuk Berwirausaha. E-Jurnal Akuntansi Universitas Udayana Vol.20.1. Juli (2017): 261289 
Pramitasari, T. D., 2018. Pengaruh manajemen keuangan pribadi dan efikasi diri terhadap intensi berwirausaha mahasiswa fakultas ekonomi UNARS. UNEJ e-Proceeding, 339-347.

Pramitasari, T. D., \& Tyasasih, R. (2019, June). Peningkatan Intensi Berwirausaha Di Kalangan Mahasiswa. In Prosiding Seminar Nasional \& Call For Paper (pp. 183-196).

Robbins, S dan Coulter, M. 2007, Manajemen. Edisi Kedelapan, Jakarta : PT Indeks.

Santosa, T. J., 2016. Faktor - Faktor Yang Berpengaruh Terhadap Minat Berwirausaha Mahasiswa STMIK Duta Bangsa Surakarta. Jurnal Sainstech Politeknik Indonusa Surakarta, 1(5).

Sina, P.G. 2013. Pengaruh Cognitive Style dan Global Mindset Terhadap Manajemen Keuangan Pribadi dan Pengaruh Manajemen Keuangan Pribadi Terhadap Intensi Berwirausaha. Jurnal Manajemen Teori dan Terapan Tahun 6. No. 1, April 2013. Fakultas Ekonomi, UKSW-Salatiga.

Suharti, L., \& Sirine, H. 2011. Faktor-faktor yang berpengaruh terhadap niat kewirausahaan (entrepreneurial intention). Jurnal Manajemen Dan Kewirausahaan, 124.

Suhartini, Y., 2011. Analisis Faktor-Faktor Yang Mempengaruhi Minat Mahasiswa Dalam Berwirausaha (Studi Pada Mahasiswa Universitas PGRI Yogyakarta). AKMENIKA UPN, 7.

Sumarsono, H. 2016. Faktor-faktor yang mempengaruhi intensi wirausaha mahasiswa universitas muhammadiyah ponorogo. Ekuilibrium: Jurnal Ilmiah Bidang Ilmu Ekonomi, 8(1), 62-88. DOI : 10.24269/ekuilibrium.v8i1.35

Supriyanto, S., \& Meilita, E. 2017. Pengaruh Pendidikan Kewirausahaan Terhadap Intensi Berwirausaha (Studi Pada Mahasiswa S1 Program Studi Administrasi Bisnis Universitas Bandar Lampung). SOSIALITA, 9(2).

Sutikno, Satriyo Adhy \& Sukmawati Nur Endah. 2012. Penerapan E-Commerce untuk Meningkatkan dan Memperluas Pemasaran di UMKM. Jurnal Fakultas Sains dan Matematika, Universitas Diponegoro.

Widoyoko, S. Eko Putro, 2016. Teknik Penyusunan Instrumen Penelitian. Yogyakarta : Pustaka Belajar.

Widiyatnoto, E. 2012. Pengaruh Jiwa Kewirausahaan dan Budaya Keluarga Terhadap Minat Berwirausaha Pada Siswa SMKN 1 Wonosari dan SMKN 2 Wonosari di Kabupaten Gunungkidul. Artikel Ilmiah Program Studi Pendidikan Teknik Mesin Fakultas Teknik Universitas Negeri Yogyakarta: Yogyakarta.

Wijayanti, Ni Gusti Putu Putri dan Suryani, Alit. 2016. Perbandingan Faktor-Faktor Yang Memengaruhi Intensi Berwirausaha Mahasiswa Feb Unud Dan Mahasiswa Feb Undiknas. E-Jurnal Manajemen Unud, Vol 5, No 3, 2016: 1862-1712

Yadewani, Dorris, Reni Wijaya. 2017. Pengaruh E-Commerce Terhadap Minat Berwirausaha (Studi Kasus : AMIK Jayanusa Padang). Jurnal RESTI (Rekayasa Sistem dan Teknologi Informasi) Vol . 1 No. 1 (2017) 64 - 69 